\title{
Wysiedlenie widziane oczami dziecka z Zamojszczyzny
}

\author{
„Nie było kiedy płakać”. \\ Losy rodzin polskich wysiedlonych z Zamojszczyzny 1942-1943. \\ T. 1-2. Oprac. Beata Kozaczyńska. Siedlce, Stowarzyszenie tutajteraz, \\ 2014, ss. 199 (T. 1), ss. 199 (T. 2).
}

Forced Displacement of Population through the Eyes of a Child from Zamojszczyzna

\begin{abstract}
Aвstract: The article undertakes the topic of forced population displacement seen through the eyes of a child from Zamojszczyzna along with war-time fates of Polish families deported during the Second World War. The history of Zamojszczyzna lands is composed of tragic experiences of people forced out of their family households, imprisoned in the transit camps, deported to be involuntary labourers in the Third Reich, or murdered in concentration camps KL Auschwitz and KL Lublin (Majdanek). The survivors had to carry on throughout their lives with an indelible mark left by war-time childhood reflected by the name "a Child of Zamojszczyna" (the said status was granted to persons who were prisoners of the transit camps in Zamość and Zwierzyniec [solely children until the age of fourteen] and those imprisoned in concentration camps [for at least one day]).
\end{abstract}

Problematyka związana z Holokaustem, eksterminacją oraz wszelkimi działaniami nazistowskimi w czasie drugiej wojny światowej jest tematem aktualnym i budzącym zainteresowanie badaczy reprezentujących rozmaite dziedziny nauki. Często mają one charakter interdyscyplinarny, sytuują się na pograniczu różnych obszarów badawczych i odmiennych metodologii. Największa wojna 
w historii ludzkości, mająca swoje podłoże w niemieckim imperializmie i nacjonalizmie, ukazywana jest zarówno ze zbiorowego, jak i z indywidualnego punktu widzenia, przy czym ten ostatni ujawnia zawsze jej najbardziej wstrząsające i przerażające oblicze, znaczone krwią i łzami.

„Zbrodnie hitlerowskie na dzieciach i młodzieży polskiej podczas drugiej wojny światowej stanowią zbrodnię ludobójstwa, a więc zbrodnię przeciwko ludzkości”. "Zbrodnia ta - jak stwierdzono w uzasadnieniu procesu norymberskiego (nr dziewięć) - nie oszczędziła ofiar spośród kobiet i dzieci, które do tych czasów nawet bezwzględny i barbarzyński wróg poczytywał sobie za obowiązek ochraniać" ${ }^{2}$. W wyniku działań wojennych w czasie drugiej wojny światowej zginęło około 2250 tysięcy dzieci mających polskie obywatelstwo, co najmniej 200 tysięcy zostało wywiezionych z Polski w celach germanizacyjnych, spośród nich powróciło tylko około 15-20\%. 710 tysięcy zostało skierowanych do przymusowych prac fizycznych, półtora miliona zaś po wojnie było sierotami, półsierotami lub dziećmi opuszczonymi ${ }^{3}$. Suche liczby i fakty nie oddają tragedii bezbronnych istot, niezawinionych ofiar niemieckiego czy sowieckiego terroru. Okrucieństwo nazistów w oczach dziecka wydaje się szczególne, wskutek wojny traci ono bowiem wszystko, zwłaszcza najbliższą rodzinę. Szybko dojrzewa, z dnia na dzień staje się innym człowiekiem. Traci zaufanie do dorosłego i poczucie bezpieczeństwa, zostaje pozbawione prawa do bycia dzieckiem, staje się ofiarą. Podczas każdej wojny dzieci doświadczają „odwróconego dekalogu”, dehumanizacji, rzeczy niewyobrażalnych, a konsekwencje tego: piętno strachu, niepewności, makabrycznych obrazów i sieroctwa, niosą przez całe życie. Anna Janko w Małej zagładzie napisze: „Odebranie dziecku matki - to dla niego stan graniczny”, „[...] dziecko ma bliżej do krawędzi otchłani i boi się zawsze o sta tecznie [...]”5. "Dzieci się miotają w rozpaczy, duszą się strachem, dławią się łzami, życie psychiczne jest dla nich żywiołem o wiele bardziej niż dla dorosłych, którzy mają już jakieś punkty odniesienia, jakieś uniwersum"6.

Właśnie tym najmłodszym, niewinnym i bezbronnym została poświęcona recenzowana książka wspomnieniowa „Nie było kiedy płakać”. Losy rodzin polskich wysiedlonych z Zamojszczyzny 1942-1943 w opracowaniu Beaty Kozaczyńskiej. Wyłania się z niej obraz wojennego dzieciństwa, dzieci przedwcześnie dojrzałych. Wybór podjętej problematyki wydaje się w pełni uzasadniony,

${ }^{1}$ Cyt. za: B. Kozaczyńska: Ocalone z transportów. Dzieci Zamojszczyzny. Siedlce 2011, s. 7.

2 C. Pilichowski: Sytuacja dzieci polskich w latach drugiej wojny światowej. W: Dzieci i młodzież w latach drugiej wojny światowej. Red. C. Pilichowski. Warszawa 1982, s. 39.

${ }^{3}$ Zob. m.in.: H. Radlińska, J. Wojtyniak: Sieroctwo. Zasięg i wyrównywanie. Warszawa 1946 lub E. Rosset: Demografia Polski. Warszawa 1975.

${ }^{4}$ A. Jаnко: Dzieci mieć - prawdziwe nieszczęście. W: TAż: Mała zagłada. Kraków 2015, s. $175-176$.

${ }^{5}$ A. Janko: Szczęście. W: TAż: Mała zagłada..., s. 80.

${ }^{6}$ A. JАNко: W płaczu zaklęta. W: TAż: Mała zagłada..., s. 166. 
Kozaczyńska od wielu lat zajmuje się bowiem tematyką wysiedlenia ludności z Zamojszczyzny - jest autorką kilkudziesięciu publikacji naukowych i popularnonaukowych skoncentrowanych wokół tej kwestii, jak również wokół historii miasta Siedlce oraz regionu siedleckiego. Spod jej pióra wyszły prace naukowe, takie jak: Losy dzieci z Zamojszczyzny wysiedlonych do powiatu siedleckiego $w$ latach 1943-1945 (Siedlce 2006) czy Ocalone z transportów Dzieci Zamojszczyzny. Losy dzieci wysiedlonych $z$ Zamojszczyzny do dystryktu warszawskiego 1942-1945 (Siedlce 2011, tłumaczenie na język angielski) ${ }^{7}$. Dwutomowy zbiór wspomnień o znaczącym tytule: „Nie było kiedy płakać”..., to wyjątkowa pozycja w dorobku badaczki ze względu na to, że wyłania się z niej tragiczna historia wysiedleń z Zamojszczyzny przedstawiona w subiektywny, a przez to emocjonalny sposób. Struktura książki oparta jest na wspomnieniach pozyskanych przez autorkę od wysiedleńców w ramach tzw. historii mówionej, oral history. Są to transkrypcje wywiadów będące obok źródeł pisanych materiałem wykorzystywanym w ujęciach interdyscyplinarnych ${ }^{8}$. Z uwagi na specyfikę przedmiotu badawczego i cel taką budowę publikacji należy uznać za właściwą, logiczną oraz w pełni oddającą poruszaną problematykę. Zastrzeżeń nie wzbudza proporcja poszczególnych tomów. Są one tożsame w odniesieniu do liczby wspomnień, materiału fotograficznego i wizualnego czy liczby stron. Na ocenę recenzowanej książki ma także wpływ rzetelnie przeprowadzona praca badawcza. Autorka pozyskała materiał wspomnieniowy od osób prywatnych, $\mathrm{z}$ zasobów Archiwum Państwowego w Zamościu, Państwowego Muzeum na Majdanku w Lublinie oraz z Fundacji „Polsko-Niemieckie Pojednanie" świadków historii - byłej więźniarki KL Auschwitz, i spisać jej relację $e^{10}$.

Monografia porusza, wstrząsa i w sposób absolutny zmienia sposób patrzenia na tragiczną historię ziemi zamojskiej. Wyłania się z niej obraz wojny widzianej oczami dziecka wypędzonego $\mathrm{z}$ rodzinnego domu, wywiezionego na przymusowe roboty do Trzeciej Rzeszy, uwięzionego w obozach przejściowych w Zamościu i Zwierzyńcu oraz w obozach koncentracyjnych KL Auschwitz i KL Lublin (Majdanek). Jest to pozycja wpisująca się w obszar polskich badań nad wojennym dzieciństwem prowadzonych $\mathrm{z}$ perspektywy pedagogiczno-psychologicznej. Ukazuje historię masowych wysiedleń na terenie okupowanej Zamojszczyzny w latach 1942-1943. Publikacja ma formę dokumentu eksterminacji niemieckiej dokonanej na rolnikach, chłopach, ludności cywilnej, a także

7 Zob. też: Byliśmy w transportach. Dzieci Zamojszczyzny. Oprac. B. KozaczyńsKa. Warszawa 2017.

${ }^{8}$ Zob. P. Filıpкowski: Historia mówiona i wojna. Doświadczenie obozu koncentracyjnego w perspektywie narracji biograficznych. Wrocław 2010. Jednym z przykładów oral history jest wydana w 2011 r. książka K. Madoń-Mitzner: Ocaleni z Mauthausen. Warszawa 2011.

9 Zob. przywoływane źródła - T. 1, s. 23; T. 2, s. 17.

${ }^{10}$ We wspomnieniu Kędzierska przywołuje wiersz obozowy pt. List oficjalny. Zob. Przeżyłam Oświęcim..., wspomnienia Wacławy Kędzierskiej, T. 2, s. 79. 
na małych dzieciach. To literatura osobliwa, stająca się dla współczesnych czytelników istotnym elementem narodowej pamięci Polaków.

Praca Kozaczyńskiej wpisuje się w popularną w ostatnich latach tendencję przywracania pamięci o niemieckich zbrodniach ukazywanych z perspektywy indywidualnych wspomnień, z pominięciem obszernego teoretycznego komentarza historycznego, obudowanego faktami i dokumentami. Celem takiego ujęcia jest rekonstrukcja codzienności wojennej odsłaniającej „świadomość potoczną”, subiektywną i emocjonalną. Przykładem takiego spojrzenia są między innymi książki Sarah Helm Kobiety z Ravensbrück... (2017) oraz Sylwii Winnik Dziewczęta $z$ Auschwitz. Głosy ocalonych kobiet (2018) ${ }^{11}$, przedstawiające rzeczywistość w niemieckich obozach koncentracyjnych. Charakterystyczną cechą tych publikacji jest pierwszoosobowa narracja, będąca elementem budującym cały tekst. W ostatnich latach zaobserwować można również wzrost zainteresowania tematyką kobiecą i szerzej: feministyczną, w badaniach nad Holokaustem ${ }^{12}$. Świadczą o tym książki zawierające zapis kobiecego doświadczenia wojny ${ }^{13}$.

Recenzowana monografia w uprawniony metodologicznie sposób korzysta z formuły wspomnieniowej, co stanowi niezwykle mocną stronę przybliżania tematyki wysiedleńczej. Za szczególnie cenny uznać należy brak ingerencji redakcyjnej w język oraz treść, co wpływa na zachowanie autentyczności opowiadanych historii. Na podkreślenie zasługuje również fakt, że książki siedleckiej badaczki opatrzone są bogatym materiałem ilustracyjnym, zawierającym mapy, plany czy zdjęcia.

\section{Krótka historia wysiedlenia na Zamojszczyźnie}

Akcja wysiedleńczo-kolonizacyjna rozpoczęła się na Zamojszczyźnie w nocy z 27 na 28 listopada 1942 roku, zakończyła zaś w połowie sierpnia roku następnego. Przeprowadzona została w myśl hasła: „Drang nach Osten” (niem. „parcie na Wschód”), które było wyznacznikiem ówczesnej polityki Niemiec i stanowiło próbę realizacji Generalnego Planu Wschodniego (Generalplan Ost, GPO). Miał on na

${ }^{11}$ S. HeLm: Kobiety z Ravensbrück. Życie i śmierć w hitlerowskim obozie koncentracyjnym dla kobiet. Przeł. K. Bażyńska-Сhojnacka, P. Сhојnacki. Warszawa 2017; S. Winnik: Dziewczęta $z$ Auschwitz. Głosy ocalonych kobiet. Warszawa 2018.

${ }^{12}$ Zob. m.in. A. Ubertowska: „Niewidzialne świadectwa”. Perspektywa feministyczna $w$ badaniach nad literatura Holokaustu. „Teksty Drugie” 2009, nr 4, s. 214-226 oraz TAż: Holokaust. Auto (tanato) grafie. Warszawa 2014.

${ }^{13}$ Zob. m.in. Zoja, J. Follain, R. Cristofari: Wszystkie jesteście niewierne! Piekło kobiet w Afganistanie. Przeł. J. Kaвat. Warszawa 2005; A. Herbich: Dziewczyny z Powstania. Kraków 2014; Ł. Modelski: Dziewczyny wojenne. Kraków 2017; B. Wachowicz: Bohaterki powstańczej Warszawy. Warszawa 2014; S. Armstrong: Wojna kobiet. Warszawa 2015 i inne. 
celu skolonizowanie wschodniej Europy w perspektywie 20-30 lat po zwycięskim zakończeniu drugiej wojny światowej. Wiązało się to $\mathrm{z}$ wysiedleniem, germanizacją i częściową eksterminacją mieszkańców. Zamojszczyzna stała się terenem eksperymentalnym. W jej skład wchodziły cztery powiaty: zamojski, hrubieszowski, biłgorajski i tomaszowski, położone w południowo-wschodniej części dystryktu lubelskiego. Wybór tego regionu nie był przypadkowy. Istotną rolę odgrywało położenie geograficzno-strategiczne, zakładające między innymi zabezpieczenie zaplecza niemieckich wojsk walczących na Wschodzie. W okresie od 6 do 25 listopada 1941 roku Niemcy przeprowadzili wysiedlenie sondażowe na Zamojszczyźnie, rok później zaś szeroko zakrojoną akcję deportacyjną obejmującą 297 wsi i około 110000 mieszkańców, w tym około 30000 dzieci (około 10000 w wyniku akcji zmarło lub zostało zamordowanych). Akcja wysiedleńcza - pisze Kozaczyńska - „zmierzała wyraźnie do germanizacji wyselekcjonowanych dzieci polskich. Już podczas pierwszej fazy wysiedleń (do 5 grudnia 1942 roku) skierowano do obozów wychowawczych w Rzeszy trzy transporty z dziećmi wysiedlonymi z Zamojszczyzny (w wieku od pół roku do dwunastu lat). Natomiast w okresie od 7 lipca do 25 sierpnia 1943 roku wywieziono na zniemczenie 4454 dzieci (po badaniach rasowych) w wieku od dwóch do czternastu lat. Ich los pozostaje do dziś nieznany"14. W tym samym czasie do gospodarstw wysiedlonych Polaków przywożono kolonistów niemieckich, pochodzących głównie z Besarabii oraz Rumunii.

Jak podkreśla autorka, Niemcy wysiedlali ludność polską w tempie błyskawicznym, pod presją czasu, brutalnie, bijąc, dokonując gwałtów i rabunków. Wypędzani mieli opuścić dom najpóźniej w ciągu godziny, zabierając ze sobą jedynie niewielki bagaż: pożywienie, naczynia do jedzenia, dokumenty, ciepłe ubrania, koce, pierzyny dla małych dzieci i starców. Wysiedleniu podlegali wszyscy mieszkańcy wsi. Opuszczanie rodzinnego dobytku, rozdzielanie rodzin odbywało się w dramatyczny sposób. O tragizmie tamtych zajść mówią wspomnienia samych wysiedleńców, którzy mimo upływającego czasu nie mogą zapomnieć wstrząsających wydarzeń. Wysiedlonych Polaków przewożono furmankami do obozów przejściowych w Zamościu i Zwierzyńcu. W Zamościu po rejestracji więźniowie przechodzili selekcję rasową, która była kolejnym etapem gehenny rodzin. Przydział do jednej z czterech grup odbywał się na podstawie „wartości rasowej". Do grupy pierwszej zaliczano osoby pochodzenia niemieckiego, do drugiej osoby przeznaczone na zniemczenie, do trzeciej zakwalifikowane na roboty przymusowe $\mathrm{w}$ Rzeszy ${ }^{15}$, osoby przyporządkowane zaś do czwartej grupy miały zostać wywiezione do KL Auschwitz (z wyjątkiem dzieci do lat czternastu i starców powyżej sześćdziesiątego roku życia). Dla każdej z tych grup przygotowano osobne baraki. Kozaczyńska pisze: „W obozie przebywało średnio kilkaset

${ }^{14}$ B. Kozaczyńska: Ocalone $z$ transportów..., s. 18.

${ }_{15} \mathrm{O}$ dalszych losach dzieci przeznaczonych do zniemczenia zob. rozdz. Z polskich dzieci produkowano Niemców. W: Teraz jesteście Niemcami. Wstrząsające losy zrabowanych polskich dzieci. Oprac. zbiorowe. Kraków 2018, s. 108 i nast. 
małoletnich więźniów. Ich liczba była zmienna, gdyż co pewien czas wywożono ich z obozu, a na to miejsce przywożono kolejnych. Bywały okresy, iż w obozie przebywało nawet 1000 dzieci. W okresie od grudnia 1942 do kwietnia 1943 zmarło w obozie 1999 dzieci"16.

Z badań przeprowadzonych przez autorkę wynika, że akcja wysiedleńczo-kolonizacyjna na Zamojszczyźnie zakładała utworzenie tzw. wsi rentowych, do których miały zostać skierowane dzieci i osoby starsze, wyselekcjonowane z grupy czwartej („bezwartościowe rasowo”). Plan ten nie został jednak zrealizowany, a wysiedleńców, głównie dzieci i starców, kierowano do różnych miejscowości w dystrykcie warszawskim. Kozaczyńska podaje, że z obozu przejściowego w Zamościu do dystryktu warszawskiego skierowano 5321 osób, w tym 2213 do powiatu garwolińskiego, 2044 do powiatu siedleckiego i 1064 do powiatu mińsko-mazowieckiego ${ }^{17}$. $\mathrm{Na}$ wieść o transportach $\mathrm{z}$ dziećmi miejscowa ludność pośpieszyła z natychmiastową pomocą ${ }^{18}$. Pierwszy transport do Siedlec przybył 31 stycznia 1943 roku o godzinie 12 i został skierowany na bocznicę kolejową. W zaplombowanych wagonach znajdowało się 998 osób, wśród nich osoby starsze oraz dzieci - 86 poniżej czwartego roku życia i $236 \mathrm{w}$ wieku od czterech do dziesięciu lat. Niejednokrotnie znajdowały się one w stanie agonalnym. Brudne, głodne, schorowane, wycieńczone, wyziębione, pozbawione opieki rodziców. Dzięki szybkiej reakcji miejscowej ludności wysiedleńców skierowano do szpitali lub rozdzielono do rodzin zastępczych w mieście i okolicznych wsiach. Akcją pomocy deportowanym zajęły się agendy terenowe Rady Głównej Opiekuńczej (RGO), działające za zgodą władz okupacyjnych. 3 lutego 1943 roku tym, którzy nie przeżyli trudów transportu lub zmarli tuż po przyjeździe do Siedlec, zorganizowano pogrzeb, zbliżony do manifestacji patriotycznej. „Przy biciu dzwonów i udziale tysięcznych tłumów wyruszono przy uroczystym nabożeństwie. 22 trumny złożono na miejscowym cmentarzu. Na widok tego strasznego korowodu śmierci szloch żałobny wstrząsnął tłumem. Łzy żałoby narodowej popłynęły po licach młodych i starych [...]"'19. Nie wszystkich udało się zidentyfikować, o czym świadczy zachowany do dziś protokół z kostnicy Szpitala Miejskiego w Siedlcach, a w nim między innymi taki zapis: „Dziewczynka niezn. nazwiska około 6 miesięcy, bosa, brązowa koszulka, sweterek różowy i czepeczek biały w niebieskie pasy [...]" (T. 1, s. 7).

16 B. Kozaczyńska: Ocalone z transportów..., s. 19.

17 Tamże, s. 24.

18 Fragment odezwy konspiracyjnego organu LZK „Żywia” (styczeń 1943 r.) brzmiał: „[...] wzywamy wszystką ludność mieszkającą przy torach i stacjach kolejowych do pilnego baczenia i stwierdzania miejsc, gdzie pojawią się dzieci. W razie wykrycia wagonów starać się jak najszybciej i najsprawniej dzieci z nich wydobyć. Gdzie się da wykupić, gdzie się da wykraść. Zaopiekować się dziećmi natychmiast. Podzielić między rodziny. Działać spokojnie, z rozwagą RATOWAĆ DZIECI! RATOWAĆ DZIECI!" (Dzieci Zamojszczyzny w Siedlcach 1943-1983. Spotkanie pokoleń w 40 rocznice ratowania dzieci Zamojszczyzny z hitlerowskich transportów. Oprac. Z. WięCKOWSKA. Siedlce 1984, s. 4).

19 B. KozAczyńska: Ocalone $z$ transportów..., s. 29. 

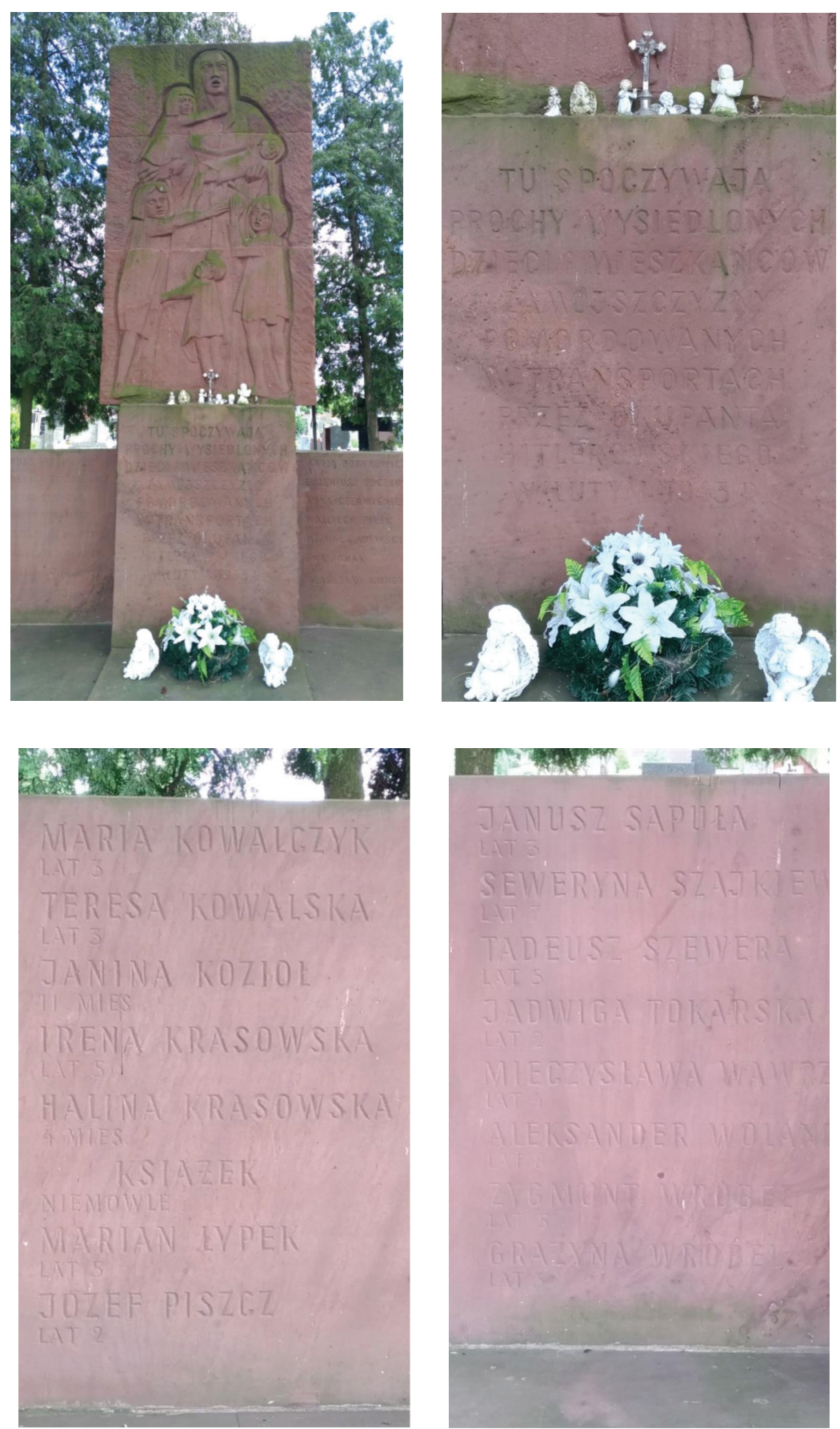

Mogiła zbiorowa i pomnik „Dzieci Zamojszczyzny” na cmentarzu przy ul. Janowskiej w Siedlcach Fot. Barbara Stelingowska 

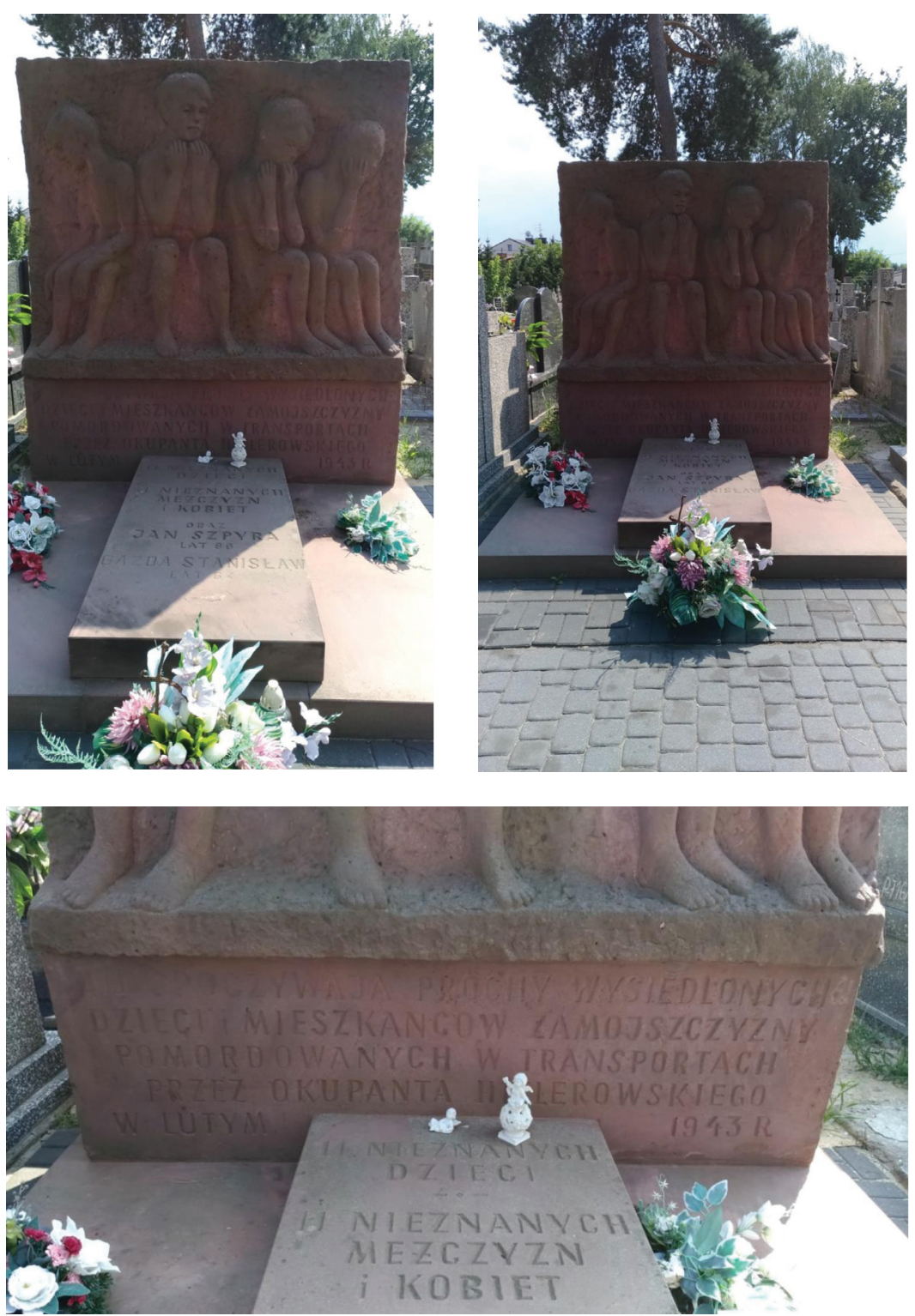

Mogiła zbiorowa i pomnik „Dzieci Zamojszczyzny” na Cmentarzu Komunalnym przy ul. Cmentarnej w Siedlcach

Fot. Barbara Stelingowska 
„Nie było kiedy płakać”

„Nie było kiedy płakać. Dali 10 minut” (T. 1, s. 9) - słowami Zygmunta Węcławika, dziewięciolatka, wysiedlonego ze wsi Skierbieszów (powiat zamojski), rozpoczyna pracę Kozaczyńska. „Celem niniejszego opracowania - pisze we Wstępie do tomu pierwszego - jest ukazanie różnorodności losów rodzin polskich wysiedlonych z Zamojszczyzny w latach 1942-1943 przez pryzmat indywidualnych przeżyć i doświadczeń" (T. 1, s. 23). Publikacja zawiera głównie wspomnienia osób mających kilka lub kilkanaście lat w chwili wypędzenia. Znajdują się wśród nich: Janina Zielińska (cztery lata), Franciszek Swacha (jedenaście lat, wywieziony przymusowo do pracy do Niemiec), Wanda Blicharz (dwa lata), Tadeusz Rozmyślak (cztery lata), Wacława Kędzierska (czternaście lat), Stanisław Syska (dziewięć lat), Jan Franciszek Lemański (dziewięć lat), Bolesław Leszczyński (dwanaście lat), Maria Anastazja Perkowska-Rusek (dwa lata i pięć miesięcy), Teresa Ferenc (dziewięć lat), Czesław Główka (dwanaście lat) czy Katarzyna Matraszek (osiem lat). Ponadto w książce przeczytać można relacje Stefana Wolfa, Bolesława Andrzejewskiego czy Wandy Cebryków, zaangażowanych w akcję pomocową wysiedleńcom z Zamojszczyzny.

Wspomnienia są tragiczne. Dominuje obezwładniający strach: „[...] gdy wychodziłam ze szkoły, to ze strachu nie wiedziałam, czy ja żyję, czy nie żyję, tylko zdawało mi się, że nas wykończą za szkołą. [...] Ja ze strachu nie mogłam iść, kobiety się rozbiegły, szłam sama jak palec" (Kiedy przyszli podpalić dom..., wspomnienia Feliksy Łukaszyk, T. 2, s. 125); „Płakałem, bo mama jeszcze się nie dostała, a ja zostałem sam, rozłączony z matką, a miałem jedenaście lat. Płakałem, ale płakali wszyscy, którzy byli na samochodzie i ci, którzy zostali" (Na przymusowych robotach w III Rzeszy, wspomnienia Franciszka Swacha, T. 2, s. 137).

Podczas akcji wysiedleńczej rozgrywały się przerażające sceny, które wyryły się w sercach i pamięci dzieci: „Jakie oni mieli serca jak tam były matki z malutkimi dziećmi na rękach, nawet były niemowlęta, co soskę miało w ustach. Wpierw strzelał do dziecka na rękach matki, a później matkę. I nawet byli staruszkowie już nad grobem" (Kiedy przyszli podpalić dom..., wspomnienia Feliksy Łukaszyk, T. 2, s. 125); „Za którymś razem po przyjeździe ze stacji hitlerowiec wyrzucił na plac ciało uduszonego chłopca. Chłopiec mógł mieć około 11-12 lat, ubrany był w granatowy płaszczyk i na głowie miał też granatową pilotkę. Buzia jego była tak ujmująco miła i spokojna, że sprawiał wrażenie śpiącego. Ciało leżało na placu do końca załadunku. Wydarzenia przeżyte w młodości przeżywa się mocniej, nie wiem jak inni, ale ja ten przypadek przeżyłam bardzo mocno, a twarz tego chłopca widziałam przed oczyma przez kilka lat" (Nie wierzyliśmy we własne szczęście..., wspomnienia Jadwigi M., T. 1, s. 99).

Największe tragedie rozgrywały się podczas segregacji rasowej, rozdzielania rodzin: 
Segregacja rodzin. Coś najpodlejszego. Scena rzezi niewiniątek z czasów Nerona, tylko w niemieckim wydaniu. Odbieranie dzieci, a raczej wyrywanie ich z rąk, z objęć matek. Segregację prowadził komendant Grunert, „Kanarkowy”. Tlenione ladacznice pomagały. Szarpały dzieci przylepione do piersi matek, uczepione do ich nóg. Wyrywały. Grunert kopał, popychał, bił. Najrozpaczliwiej broniła swego jedynego dziecka Nowogrodzka. Młoda, sama jak dziecko. Stalowe miała dłonie. Nie pomogło szarpanie. Wrzask SS-mana. Przekleństwa, mocne kopnięcie „Kanarkowego” i Nowogrodzka z niemowlęciem wpadła na rozpalony żelazny piec. Przewróciła się razem z piecem. Poparzona upadła na podłogę. Dziecko wypadło jej z rąk. Zabrali. „Kanarkowy” dobrze wypełniał swoje posłannictwo. Po scenie z Nowogrodzką nie mogłem dalej patrzeć i słuchać. Wcisnąłem się w kąt sali, gdzie było najciaśniej. Usiadłem na podłodze. Uszy mocno zatkałem palcami. Wówczas pomyślałem: czy piekło, jeśli istnieje, może być straszniejsze od tego, co się działo w tej sali? Czy może być coś straszniejszego?

Wysiedlenie Skierbieszowa, wspomnienia Zygmunta Węcławika, T. 1, s. 33

Dzieci Zamojszczyzny wspominają uwłaczające ludzkiej godności warunki obozowe czy transporty w wagonach przeznaczonych do przewożenia zwierząt:

[...] wymknąłem się więc, żeby odwiedzić babkę. Kiedy wszedłem do jej baraku uderzył we mnie okropny zaduch. Był to barak - stajnia, środkiem, przez całą długość, biegł szeroki korytarz. Obie strony podzielone były na boksy dla koni. W środku koński gnój wymieszany z ziemią, a na tym, na swoich szmatach i tobołach, siedzieli ludzie - sami starcy, obojga płci. Przez kilka ostatnich tygodni zniedołężnieli do reszty. Niektórzy załatwiali własne potrzeby wprost pod siebie, niektórzy umierali. W baraku panował półmrok, ogrzewania oczywiście nie było. Staruszkowie trwali jakby w odrętwieniu, leżąc i siedząc w tych boksach.

Wysiedlenie Wielączy-Kolonii, wspomnienia Bolesława Leszczyńskiego, T. 2, s. 116

I tu w zamojskim obozie przywitały nas insekty, choć dostateczną ilość przywieźliśmy ze sobą ze Zwierzyńca. To była dokuczliwa plaga. Ludzie w różny sposób bronili się. Obierali się, trzepali ubrania, ale to niewiele pomagało. Najgorzej wyglądały dzieci. One znały tylko jeden sposób - drapanie się. Okropnie wyglądały z tymi rozdrapanymi, krwawiącymi bruzdami na twarzy, na rękach, na nogach i na szi.

Fragment mojego życiorysu z lat 1939-1945, wspomnienia Czesława Główki, T. 2, s. 165

[...] Na stacji w Siedlcach byłyśmy kupką smrodu. Wyłuskano nas spod tych łachów. Bokami wagonów spływały fekalia, dzieci w zimowych, ciężkich ubraniach, pełnych robactwa.

Cztery siostry. Echa najdalszych wspomnień, wspomnienia Janiny Zielińskiej, T. 1, s. 57-58

Opracowany przez Kozaczyńską dokument pełni funkcję terapeutyczną dla osób, które zgodziły się opowiedzieć historię wysiedlenia swojej rodziny. 
Porównać go można $\mathrm{z}$ historią wojenną widzianą oczami kobiet, opisaną przez białoruską pisarkę Swietłanę Aleksijewicz w książce Wojna nie ma w sobie nic $z$ kobiety $^{20}$. Kozaczyńska, podobnie jak białoruska noblistka, przeprowadziła wielogodzinne rozmowy oraz wysłuchała niezwykle dramatycznych opowieści ${ }^{21}$. Obie publikacje cechuje wysoki stopień szczegółowości, co w oczywisty sposób podnosi ich wartość merytoryczną.

\section{Oczami dziecka}

W recenzowanej pracy można odnaleźć również wspomnienia przedstawione w artystyczny (obrazki) i literacki (wiersze) sposób. Z 1946 roku pochodzą wykonane przez dzieci ze szkół podstawowych z województwa lubelskiego rysunki, które obecnie znajdują się w zasobach Archiwum Akt Nowych w Warszawie ${ }^{22}$. Warto zauważyć, że fragmenty bądź niekiedy całe obrazki znajdują się w obu tomach „Nie było kiedy płakać”...23.

Uderzające jest to, że w dziecięcych rysunkach nie ma charakterystycznych dla nich pogodnych przedstawień przyrody czy scen z mamą, są za to obrazy będące odzwierciedleniem wspomnień $\mathrm{z}$ najwcześniejszych lat dzieciństwa. Narysowane sceny dookreślają tytuły: Wysiedlanie Polaków przez Niemców, Mordowanie Polaków, Wieszanie Polaków w lesie, Niemcy katuja Polaka, Warszawa się pali, Na śmierć, Niemcy prowadza ludzi na Majdanek, Walka w lesie, Bombardowanie miasta, Kapitulacja Niemiec itp. Wyryte w pamięci obrazy są rzeczywiste i realne, nie ma w nich miejsca na abstrakcję czy artystyczne wyobrażenie. Dzieci starały się również oddać towarzyszące wydarzeniom emocje. Namalowane postaci podnoszą więc ręce do góry, krzyczą, mają twarze wykrzywione przerażeniem, płaczą, leżą w kałuży krwi, uciekają, upadają, wyglądają na wystraszone itp. Dostrzec można wyraźną opozycję między ofiarą a okupantem, wyrażającą się $\mathrm{w}$ postawie i ubiorze. Więzień obozu koncentracyjnego jest wychudzony, biedny, zgarbiony, ubrany w podarty pasiak, nad nim zaś góruje

${ }^{20}$ S. Aleksijewicz: Wojna nie ma w sobie nic $z$ kobiety. Przeł. J. Czech. Wołowiec 2015. Zob. też B. STelingowska: „Wojna nie ma w sobie nic z kobiety” - wokół reportażu Swietłany Aleksijewicz. W: Oblicza współczesnych wojen. Red. M. Kubiak, R. Wróblewski. Warszawa-Siedlce 2018, s. 389-407.

${ }^{21}$ Zostały one opublikowane w książce, zob. Byliśmy w transportach...

${ }^{22}$ http://www.aan.gov.pl/art,535,wojna-i-okupacja-w-oczach-dziecka [data dostępu: 24.07.2019].

${ }^{23}$ B. Kozaczyńska jest autorką scenariusza i kuratorem wystawy historycznej pt. „Ocalone z transportów Dzieci Zamojszczyzny" (2013), dofinansowanej m.in. przez Ministerstwo Obrony Narodowej, oraz „Dzieci Zamojszczyzny: historie prawdziwe” (wystawa polsko-angielska), przygotowanej dla Ministerstwa Spraw Zagranicznych. Jest również stypendystką Ministra Kultury i Dziedzictwa Narodowego $(2007,2011)$ oraz Instytutu Pileckiego w Warszawie (2019). 
postawny człowiek w wysokich butach, z czapką oficerską na głowie, bronią w ręku i na ramieniu, z nahajką i swastyką namalowaną na ubraniu lub hełmie. Rysunki wykonane są najczęściej ołówkiem, bywają także obrazki kolorowe, $\mathrm{z}$ dominującym kolorem czerwonym (krew, ogień, wybuch, flaga).

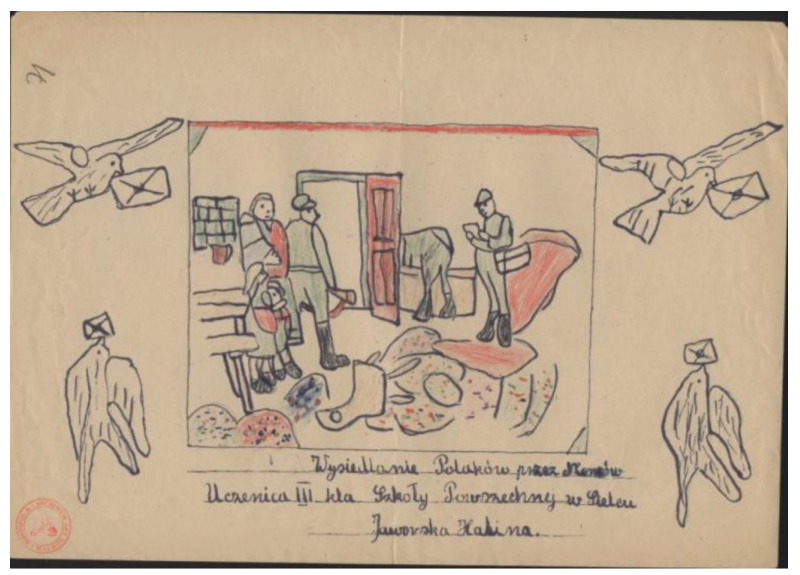

Wysiedlanie Polaków przez Niemców; uczennica III kla. Szkoły Powszechnej w Sielcu, Jaworska Kalina

Źródło: Archiwum Akt Nowych w Warszawie ${ }^{24}$

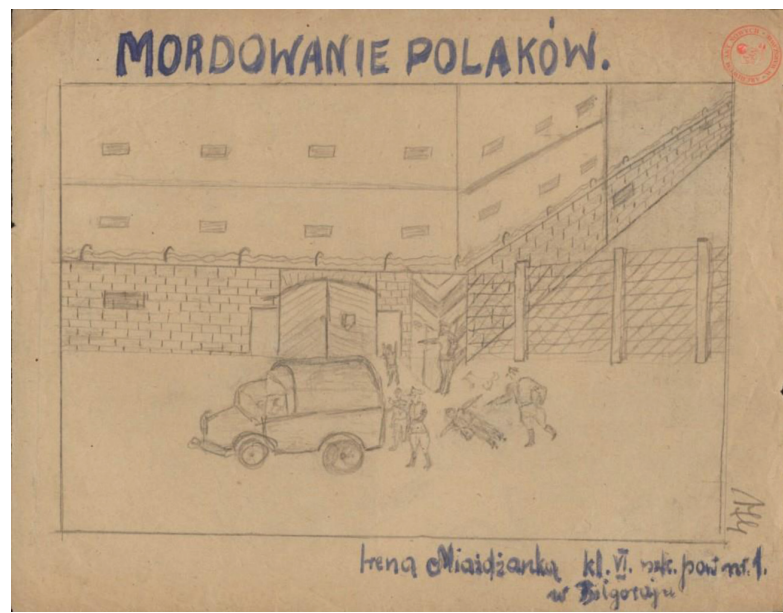

Mordowanie Polaków, Irena Miażdżanka, kl. VI. szk. podst. nr 1 w Biłgoraju Źródło: Archiwum Akt Nowych w Warszawie ${ }^{25}$

${ }^{24} \mathrm{https} / / /$ niezalezna.pl/234721-pieklo-wojny-widziane-oczami-dzieci-rysunki-uczniow-dajawstrzasajace-swiadectwo oraz http://www.aan.gov.pl/art,535,wojna-i-okupacja-w-oczach-dziecka [data dostępu: 24.07.2019].

${ }^{25}$ Tamże. 
Opisywane ilustracje stanowią osobliwą szatę graficzną oraz dokumentują recenzowane opracowanie Beaty Kozaczyńskiej. W sposób szczególny uświadamiają, że opowiadane historie, chociaż wspominane przez osoby dorosłe, dotyczą ich lat dziecięcych. Obrazki narysowane przez najmłodszych, skrupulatnie wybrane przez autorkę, podkreślają wpływ „nieludzkiego czasu” na zmiany psychosomatyczne zachodzące u dzieci tragicznie wplątanych w wojnę dorosłych.

Książka Kozaczyńskiej to publikacja o wysokim poziomie merytorycznym. Zauważalną zaletą jest umiejętnie nakreślone tło faktograficzne; autorka opracowania we wstępie do obu tomów posiłkuje się między innymi fragmentami wspomnień i relacjami świadków zdarzeń. Całość uzupełniają archiwalne zdjęcia (z datą i miejscem), wraz z nazwiskami i gruntownie opisanymi rodzinnymi korelacjami, jak również osadzone w przestrzeni geograficznej nazwy miejscowości. Obok licznych zdjęć legitymacji, listów i zaświadczeń znajdują się także fotokopie wykazu dzieci zabranych do obozu w Zwierzyńcu (fragment) oraz wypracowanie szkolne Salomei Kurtys. Dwunastoletnia dziewczynka w pracy pt. Wrażenia $z$ mego wysiedlenia napisała: „Gdy nas drugi raz wysiedlili ze Skierbieszowa zawieźli nas do baraków za druty tam mieliśmy jak w czyszczu. Z baraków wygnali nas na plac i tam odłączali ojców osobno i matki z dziećmi osobno. Gdyż bardzo płakaliśmy bo nam zabrali tate do Berlina, a my z mamą przyjechaliśmy do Żelechowa do szkoły" (T. 2, s. 78) ${ }^{26}$. Dziecko to przeżyło dwukrotne wysiedlenie: w 1940 roku z Pomorza do obozu przejściowego w Łodzi, stamtąd do Skierbieszowa, a dwa lata później - do obozu przejściowego w Zamościu. Z Zamościa Niemcy wywieźli Salomeę wraz z rodziną do Sobolewa, a stamtąd do Żelechowa (dystrykt warszawski). Podobnych przypadków było więcej. Trudno sobie wyobrazić, jakie spustoszenie psychiczne wywołała dwuletnia tułaczka u dwunastoletniego dziecka, żyjącego w ciągłym strachu, niepewności i poczuciu braku bezpieczeństwa.

Stanisława Gontarska - Dziecko Zamojszczyzny - wysiedlona ze wsi Niedzieliska (powiat zamojski), swoje wspomnienia zawarła w formie literackiej. Najbardziej znanym jej wierszem jest utwór Oczami dziecka, który ukazuje rzeczywistość wojenną jego oczami i z jego pozycji. To właśnie ten punkt widzenia staje się osią konstrukcyjną wiersza podzielonego na cztery dziewięciowersowe części. Pierwsza z nich, którą można nazwać „na wysokości [podkr. - B.S.] oczu dzieci”, opisuje spotkanie „oko w oko" z wywołującym strach i przerażenie niemieckim psem ${ }^{27}$. W drugiej części - „do wysokości [podkr. - B.S.] oczu dziecka” - opisane zostały buty i „płaszcz z dużymi guzikami” charakteryzujące część hitlerowskiego stroju. W trzeciej zaś części - „ponad wysokość [podkr. - B.S.] oczu dzieci” (T. 1, s. 47) - ujawnia się obraz rzeczywistości obo-

${ }^{26}$ Zachowana została oryginalna pisownia.

${ }^{27}$ Por. M. Pastoureau: Diabelska materia. Historia pasków i tkanin w paski. Przeł. M. Оснав. Warszawa 2004. 
zowej z ciągnącym się w nieskończoność kolczastym ogrodzeniem, wysokimi barakami, nade wszystko zaś ze stosem ciał układanych ludzkimi rękami. Część czwarta jest refleksją dorosłego człowieka pozostającego nieustannie (w przypadku autorki wiersza) Dzieckiem Zamojszczyzny.

Monografia „Nie było kiedy płakać”. Losy rodzin polskich wysiedlonych z Zamojszczyzny 1942-1943 w opracowaniu Beaty Kozaczyńskiej została dofinansowana przez Fundację Banku Zachodniego WBK w ramach programu grantowego „Bank Ambitnej Młodzieży”. W Słowie wstępnym do tomu pierwszego autorstwa Elizy Dzwonkiewicz (Prezes Zarządu Fundacji) czytamy:

Wspominając „Dzieci Zamojszczyzny” myślimy o maleńkich dzieciach, zmarłych w transporcie lub w obozach. Myślimy również o tych wywiezionych do Niemiec, zgermanizowanych - wyrwanych z ramion nie tylko rodzicom, ale i własnej Ojczyźnie. Świadectwa tamtych czasów mamy jednak głównie od tych, które będąc dziećmi - w tym bezbrzeżnym oceanie zła, miały wielkie szczęście, bo zostały odzyskane, odkupione lub wykradzione z wagonów przez poruszonych ich losem mieszkańców Siedlec, Warszawy...

T. 1 , s. 7

Do ukazania się tej publikacji przyczyniła się również Fundacja „Polsko-Niemieckie Pojednanie”, której Przewodniczący Zarządu Dariusz Pawłoś w Słowie wstępnym do tomu drugiego napisał:

[...] publikacja ta z pewnością zainteresuje i wzruszy każdego Czytelnika, ale przede wszystkim powinny sięgnąć po nią osoby, które nie miały jeszcze okazji poznać bliżej tragicznej historii Ziemi Zamojskiej. Obraz wojny i okupacji, jaki wyłania się ze stron tej książki, to w dużym stopniu obraz widziany oczami dzieci, dlatego polecamy ją także młodym Czytelnikom. Z pewnością trafi do ich wyobraźni, pozwoli lepiej zrozumieć suche historyczne fakty, dostarczy materiału do refleksji...

T. 2, s. 6

Kozaczyńska opracowała niezwykły dokument będący świadectwem okrucieństwa i barbarzyństwa okupanta, gehenny dzieci uwięzionych w obozach przejściowych i koncentracyjnych oraz ich dalszych, trudnych powojennych losów. Jest on podziękowaniem wszystkim tym, którzy z odruchu serca zaopiekowali się wysiedleńcami i użyczyli im dachu nad głową. Nade wszystko zaś jest ta książka wołaniem o pamięć, zwłaszcza w imieniu dzieci - bezimiennych, nieznanych i nigdy nieodnalezionych.

BArbara Stelingowska - dr, adiunkt w Instytucie Językoznawstwa i Literaturoznawstwa Uniwersytetu Przyrodniczo-Humanistycznego w Siedlcach. Jej zainteresowania badawcze koncentrują się na literaturze i kulturze XIX i XX wieku. Opublikowała 
trzy książki: Poezja „idylliczna” Marii Komornickiej. Szkic interpretacyjny. T. 1 (2017), Poezja „idylliczna” Marii Komornickiej. Dialog, idylla i romans. T. 2 (2019), „Modernizm kobiecy" w literaturach słowiańskich (na przykładzie twórczości Marii Komornickiej i Anny Mar) (2015). W swoich badaniach podejmuje m.in. tematy inności, tożsamości; interesuje się również obszarem epistolograficznym i biograficznym. Współredaktorka tomów zbiorowych: Arachnofobia. Metaforyczne odsłony kobiecych lęków (z Beatą Walęciuk-Dejneką; 2013), Formy czasu i szaleństwa w literaturze i sztuce (z Ewą Kozak; 2014), Literatura i globalizacja (z Elżbietą Kur; 2017), „Высокий лад глубокий мир”: между реализмом и постмодернизмом (z Ewą Kozak, Walentyną Krupowies, Joanną Tkaczyk; 2018), Literatura i wielość kultur (z Elżbietą Kur; 2019). 